\title{
Resistance induction efficiency of silicon dioxide against Meloidogyne incognita in tomato
}

\section{Eficiencia de dióxido de silicio en la inducción de la resistencia del tomate a Meloidogyne incognita}

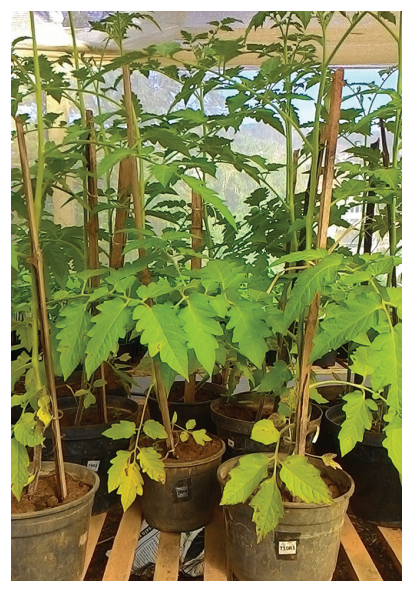

EDILSON MARQUES JUNIOR ${ }^{1,2}$

JORGE TADEU FIM ROSAS ${ }^{1}$

ALIXELHE PACHECO DAMASCENA ${ }^{1}$

MATHEUS ALVES SILVA'

GUILHERME DE RESENDE CAMARA'

ÂNGELO OLIVEIRA GONÇALVES ${ }^{1}$

WILLIAN BUCKER MORAES'

Tomato plants in greenhouse.

Photo: E.M. Junior

\begin{abstract}
The tomato root-knot nematode is one of the main phytosanitary problems in crops. Chemical control is the phytosanitary method most used by farmers, and the study of alternative management of phytonematodes is crucial. The objective of this study was to evaluate the effect of silicon dioxide $\left(\mathrm{SiO}_{2}\right)$ on the initial development of tomato plants, as well as to determine the best dose of $\mathrm{SiO}_{2}$ for inducing resistance to parasitism by $M$. incognita. This experiment was set up under a completely randomized design with ten treatments and five replicates in a $5 \times 2$ factorial arrangement consisting of five concentrations of $\mathrm{SiO}_{2}\left(0,0.15,0.3,0.45\right.$ and $0.6 \mathrm{~g} \mathrm{dm}^{-3}$ of soil) with the presence and absence of $M$. incognita, under greenhouse conditions. The following variables were evaluated: plant height; number of leaves; fresh and dry weight of shoot; percentage of shoot dry matter; root fresh weight; number of galls; final population of nematodes; and population per gram of root. The $M$. incognita infection affected plant height, number of leaves and shoot fresh weight, while the application of $\mathrm{SiO}_{2}$ negatively affected the formation of galls in the roots of the inoculated plants and the population per gram of root, reducing the final population of nematodes in the root system. $\mathrm{SiO}_{2}$ also provided greater development in the tomato plants, with a significant effect on plant height. The ideal dose was $0.34 \mathrm{~g} \mathrm{dm}^{-3}$ of $\mathrm{SiO}_{2}$.
\end{abstract}

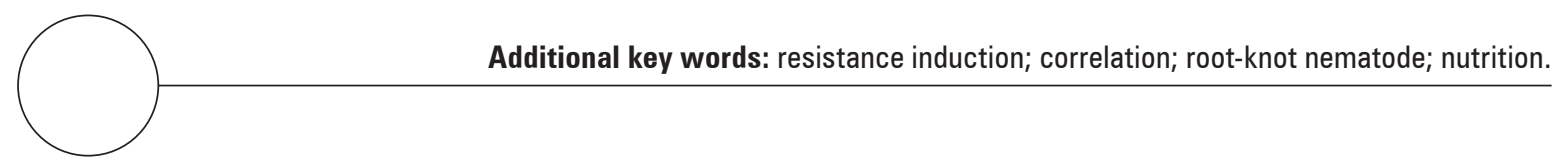

1 Universidade Federal do Espírito Santo, Center for Agricultural Sciences and Engineering, Department of Agronomy, Alegre (Brazil). ORCID Junior, E.M.: 0000-0003-4216-1980; ORCID Rosas, J.T.F.: 0000-0002-3244-4816; ORCID Damascena, A.P.: 0000-0003-1374-5119; ORCID Silva, M.A.: 0000-0002-4992-9588; ORCID Camara, G.R.: 0000-0001-8181429X; ORCID Gonçalves, A.O.: 0000-0003-3151-4875; ORCID Moraes, W.B.: 0000-0001-7478-7772

2 Corresponding author. edilsonmarquesjr@hotmail.com 


\section{RESUMEN}

Los nematodos se encuentran dentro de los principales problemas fitosanitarios del cultivo de tomate. El control químico es el método fitosanitario más utilizado por los productores y la búsqueda de medidas alternativas para su control se hacen indispensable. El objetivo de esta investigación fue evaluar el efecto del dióxido de silicio $\left(\mathrm{SiO}_{2}\right)$ en el desarrollo inicial de plantas de tomate, así como determinar las mejores dosis en la inducción de resistencia al parásito $M$. incognita. Se estableció un diseño completamente al azar, con diez tratamientos y cinco repeticiones, en arreglo factorial $5 \times 2$, consistiendo en cinco concentraciones de $\mathrm{SiO}_{2}(0 ; 0,15 ; 0,3 ; 0,45$ y $0,6 \mathrm{~g} \mathrm{dm}^{-3}$ de suelo) y la presencia y ausencia de $M$. incognita, en invernadero. Se evaluaron las variables altura de la planta, número de hojas, masa fresca y seca de la parte aérea, porcentaje de materia seca de la parte aérea, masa fresca de la raíz, número de agallas, población final y por gramo de raíz de nematodos. La infección por M. incognita afectó las variables altura de las plantas, número de hojas y masa fresca de la parte aérea, mientras que la aplicación de $\mathrm{SiO}_{2}$ afectó de forma negativa la formación de ramas en las raíces de las plantas inoculadas y la población por gramo de raíz, reduciendo la población final de nematodos en el sistema radicular de las plantas. La aplicación de $\mathrm{SiO}_{2}$ también proporcionó mayor desarrollo a las plantas de tomate, presentando

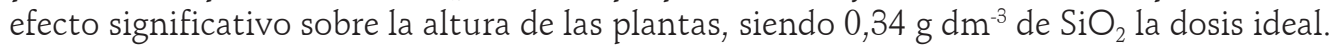

Palabras clave adicionales: inducción de resistencia; correlación; nematodo agallador; nutrición.

Received for publication: 07-03-2018 Accepted for publication: 29-03-2019

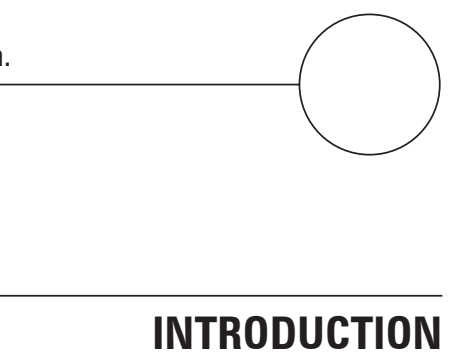

The cultivation of tomato (Lycopersicon esculentum Mill.) is notable for its high world consumption, whether raw or processed, with great socioeconomic importance (Ferreira et al., 2017). Because it is a highly profitable activity with wide acceptance in the consumer market, the tomato is the most commercially important vegetable crop in Brazil, with an average production of 4 million tons of fruits harvested annually, in an area of approximately 60,000 ha (IBGE, 2016).

Of the several biotic and abiotic factors that hinder tomato production and productivity, the root-knot disease, caused by nematodes of the genus Meloidogyne Goeldi 1887, stands out as one of the main phytosanitary problems in this crop, limiting yield throughout the world (Rosal et al., 2014). Thus, this activity takes onhigh economic risk because of the high investments necessary for planting this crop (Carvalho et al., 2014).

Economically, the most significant nematode species in the country for tomato crops are Meloidogyne javanica, $M$. incognita, $M$. ethiopica and $M$. arenaria because of their pathogenicity, high losses, reduction of final product quality (Hunt and Handoo, 2009), broad geographical distribution, wide range of hosts (Pinheiro et al., 2014) and management complexity (Damalas and Eleftherohorinos, 2011).

Chemical control is the phytosanitary method most used by producers. Although efficient, chemical molecules are highly toxic to humans, animals and ecosystems (Damalas and Eleftherohorinos, 2011). In this context, the study of alternative measures for the control of phytonematodes has become crucial, provided that the aim is the adoption of practices that minimize pressure on the environment (Timper, 2014; Pastori et al., 2017; Bhatt and Sharma, 2018).

The benefits of silicon accumulation and its success in the management of various pathogens have already been demonstrated for several crops, e.g. Wang et al. (2017). For nematodes, success has been shown for M. javanica in bananas (Oliveira et al., 2012), rice, beans and soybeans (Mattei et al., 2015), for M. incognita in tomatoes (Melo et al., 2012), and for Enneothrips flavens Moulton 1941 in peanuts (Dalastra et al., 2011), among others.

It is known that the characteristics of silicon allow its use in management programs because of stiffening 
of plant cell walls and influence on the synthesis of toxins in the biochemical responses of plants and in the gene expression of defense proteins (Dannon and Wydra, 2004; Wang et al., 2017). However, despite advances in research that promote use of this new and promising form of phytonematode management in the field, little is known about which silicon dosages are more efficient in the management of this pathogen and do not negatively affect the nutritional conditions of plants.

The objective of this study was to evaluate the effect of silicon dioxide $\left(\mathrm{SiO}_{2}\right)$ on the initial development of tomato plants, as well as to determine the best doses of $\mathrm{SiO}_{2}$ in the induction of plant resistance to parasitism by $M$. incognita.

\section{MATERIAL AND METHODS}

This study was conducted in a greenhouse located at the Center of Agrarian Sciences and Engineering of the Federal University of Espírito Santo - CCAE/ UFES, Alegre-ES $\left(20^{\circ} 42^{\prime} \mathrm{S}\right.$ and $41^{\circ} 27^{\prime} \mathrm{W}$, at $269 \mathrm{~m}$ a.s.1.). The climate of the region, according to the Köppen classification, is type "Aw", characterized by hot and rainy summers and dry winters. The average annual temperature is $23^{\circ} \mathrm{C}$, with annual rainfall around $1,200 \mathrm{~mm}$.

This experiment was set up in a completely randomized design with ten treatments and five replicates in a $5 \times 2$ factorial scheme consisting of five concentrations of $\mathrm{SiO}_{2}\left(0,0.15,0.3,0.45\right.$ and $0.6 \mathrm{~g} \mathrm{dm}^{-3}$ of soil $)$ with the presence or absence of $M$. incognita (zero and 1,500 second stage juveniles, J2 + eggs). The $\mathrm{SiO}_{2}$ source was the commercial product AgriSil ${ }^{\circledR}$ (98\% $\mathrm{SiO}_{2}, \mathrm{pH}$ 7.5-8), and the doses were 0, 50, 100, 150 and $200 \%$, adapted from the recommendation of Alvarez and Ribeiro (1999).

Tomato seeds, Santa Cruz variety, were planted on a tray with 128 cells containing Bioplant ${ }^{\circledR}$ commercial substrate, and the seedlings were transplanted $21 \mathrm{~d}$ after sowing into pots containing $4 \mathrm{dm}^{3}$ of medium textured red-yellow latosol-based substrate. The fertility management was done according to the recommendation of Prezotti et al. (2007). Five days after seedling transplant, $\mathrm{SiO}_{2}$ was diluted in water and applied individually via irrigation directly to the pots, with the respective doses of each treatment.

Seven days after applying the product, 1,500 second stage $M$. incognita juveniles (J2 + eggs) were inoculated in each pot. The plants were monitored constantly to avoid the presence of diseases and pests. The control of invasive plants was done manually. The soil moisture was maintained close to field capacity, at around $60 \%$, with daily irrigation shifts.

After $30 \mathrm{~d}$ of nematode inoculation, the following parameters were evaluated: plant height $(\mathrm{PH})$, number of leaves (NL), shoot fresh weight (SFW), shoot dry weight (SDW), percentage of dry matter (DM \%), root fresh weight (RFW), number of galls (NG), final nematode population (FP), and population per gram of root (Pgr). The nematode extraction was done according to the method proposed by Hussey and Barker (1973), as modified by Bonetti and Ferraz (1981).

The data obtained for each of the evaluated variables were submitted to analysis of variance and the doses were adjusted by regression. The means of the variables related to the presence or absence of $M$. incognita were compared by t-test at $5 \%$. The normality of the data was verified using the Kolmogorov-Smirnov test $(P \leq 0.05)$, and Pearson linear correlation $(P \leq 0.05)$ was used among the variables.

\section{RESULTS AND DISCUSSION}

The variables SFW, PH and NL were significantly affected by the presence of nematodes (Tab. 1), where in the majority of the treatments, the means differed statistically, affirming that the presence of the pathogen culminates in lower development of tomato plants, with a lower weight gain. This information is consistent with results obtained by Melo et al. (2012) and Moreira and Ferreira (2015), who characterize dwarfism as one of the main symptoms of tomato nematode infections (Dias et al., 2016). In addition to having compromised growth, the infested plants had an apparent reduction of total leaf area, because of a smaller number of leaves, which negatively affected their photosynthetic capacity. Peluzio et al. (1999) and Guimarães et al. (2009) proved that fruit filling is directly related to leaf area and number of leaves since leaves behave as a source of photoassimilates to fruits, which are sinks. According to these authors, the highest gain in leaf area occurs at the initial stage of crop development and is determinant throughout the tomato crop cycle.

For the variables SDW and RFW, the means of the plants infested by the pathogen were smaller than those not infested, but did not differ statistically, 
Table 1. ANOVA of the agronomic variables comparing their means in the presence and absence of nematodes.

\begin{tabular}{|c|c|c|c|c|c|c|c|c|}
\hline \multirow[b]{2}{*}{ Dose } & \multicolumn{4}{|c|}{ SFW (kg) } & \multicolumn{4}{|c|}{ SDW $(\mathrm{kg})$} \\
\hline & $\mathrm{C} / \mathrm{N}$ & SE & $\mathrm{S} / \mathrm{N}$ & SE & $\mathrm{C} / \mathrm{N}$ & SE & $\mathrm{S} / \mathrm{N}$ & SE \\
\hline $0 \%$ & $0.034 \mathrm{a}$ & 0.0021 & $0.067 \mathrm{~b}$ & 0.0048 & $0.011 \mathrm{a}$ & 0.0022 & $0.020 \mathrm{a}$ & 0.0045 \\
\hline $50 \%$ & $0.059 a$ & 0.0083 & $0.062 \mathrm{a}$ & 0.0050 & $0.017 \mathrm{a}$ & 0.0046 & $0.019 a$ & 0.0024 \\
\hline $100 \%$ & $0.053 \mathrm{a}$ & 0.0048 & $0.079 \mathrm{~b}$ & 0.0098 & $0.019 a$ & 0.0032 & $0.025 a$ & 0.0069 \\
\hline $150 \%$ & $0.035 \mathrm{a}$ & 0.0022 & $0.076 \mathrm{~b}$ & 0.0048 & $0.010 \mathrm{a}$ & 0.0026 & $0.015 a$ & 0.0035 \\
\hline \multirow[t]{2}{*}{$200 \%$} & $0.039 a$ & 0.0071 & $0.063 b$ & 0.0053 & $0.074 \mathrm{a}$ & 0.0025 & $0.014 \mathrm{a}$ & 0.0036 \\
\hline & \multicolumn{4}{|c|}{ RFW (kg) } & \multicolumn{3}{|c|}{ NL } & \\
\hline Dose & $\mathrm{C} / \mathrm{N}$ & SE & $\mathrm{S} / \mathrm{N}$ & SE & $\mathrm{C} / \mathrm{N}$ & SE & $\mathrm{S} / \mathrm{N}$ & SE \\
\hline $0 \%$ & $0.013 a$ & 0.0006 & $0.012 \mathrm{a}$ & 0.0029 & $7.6 \mathrm{a}$ & 0.40 & $8.4 \mathrm{a}$ & 0.40 \\
\hline $50 \%$ & $0.014 \mathrm{a}$ & 0.0017 & $0.023 b$ & 0.0026 & $7.8 \mathrm{a}$ & 0.37 & $10.8 \mathrm{~b}$ & 0.97 \\
\hline $100 \%$ & $0.020 \mathrm{a}$ & 0.0029 & $0.018 \mathrm{a}$ & 0.0018 & $8.2 \mathrm{a}$ & 0.58 & $9.6 b$ & 0.24 \\
\hline $150 \%$ & $0.013 \mathrm{a}$ & 0.0014 & $0.013 b$ & 0.0020 & $7.4 \mathrm{a}$ & 0.24 & $9.2 b$ & 0.37 \\
\hline \multirow[t]{2}{*}{$200 \%$} & $0.010 \mathrm{a}$ & 0.0021 & $0.019 b$ & 0.0028 & $7 \mathrm{a}$ & 0.55 & $9.2 b$ & 0.37 \\
\hline & \multicolumn{4}{|c|}{$\mathrm{PH}(\mathrm{m})$} & & DM (\%) & & \\
\hline Dose & $\mathrm{C} / \mathrm{N}$ & SE & $\mathrm{S} / \mathrm{N}$ & SE & $\mathrm{C} / \mathrm{N}$ & SE & SN & $S / E$ \\
\hline $0 \%$ & $0.64 \mathrm{a}$ & 0.011 & $0.65 a$ & 0.014 & $32.39 \mathrm{a}$ & 6.81 & $28.95 \mathrm{a}$ & 6.56 \\
\hline $50 \%$ & $0.614 \mathrm{a}$ & 0.025 & $0.73 b$ & 0.024 & 30.69 a & 9.55 & $30.29 a$ & 2.79 \\
\hline $100 \%$ & $0.63 \mathrm{a}$ & 0.021 & $0.80 \mathrm{~b}$ & 0.023 & $33.91 \mathrm{a}$ & 2.87 & $30.23 \mathrm{a}$ & 7.72 \\
\hline $150 \%$ & $0.57 \mathrm{a}$ & 0.015 & $0.78 b$ & 0.028 & $29.89 a$ & 7.14 & $19.09 a$ & 3.90 \\
\hline $200 \%$ & $0.55 \mathrm{a}$ & 0.027 & $0.72 b$ & 0.032 & $17.94 \mathrm{a}$ & 4.30 & $21.35 \mathrm{a}$ & 3.88 \\
\hline
\end{tabular}

SFW: shoot fresh weight in kg; SDW: shoot dry weight in kg; PH: plant height in meters; RFW: root fresh weight; NL: number of leaves; DM (\%): percentage of dry matter; $\mathrm{C} / \mathrm{N}$ : plants infected by nematodes; S/N: plants not infected by nematodes; SE: standard error of the mean. Means followed by different letters differ statistically according to the test $(P \leq 0.05)$.

in the majority of the treatments. Dias et al. (2016) found similar results; thus, these variables do not explain with confidence the effects of this pathogen on plants at the initial stage of development. The mean of the DM (\%) variable also did not differ statistically.

The analysis of variance of the effect of $\mathrm{SiO}_{2}$ on the tomato plants showed that plant height was significantly influenced, where the use of $\mathrm{SiO}_{2}$ resulted in higher growth. However, high doses of $\mathrm{SiO}_{2}$ cause an inverse effect, i.e., the plants presented reduced growth, which can be explained by the indirect effect of silicon on the absorption of zinc. High doses of $\mathrm{SiO}_{2}$ make the amount of phosphorus available in the soil high, precipitating available zinc in the form of zinc phosphate (Paim et al., 2006) and compromising the development of tomato plants since this nutrient is essential to the development of this crop.

Figure 1 shows the curve formed by the quadratic model that explains the growth of the tomato plants as a function of the addition of $\mathrm{SiO}_{2}$ to the soil, where the best growth is found at the maximum point of the regression curve. Thus, the dose that provided the highest height was $116.63 \%$, equivalent to 0.34 $\mathrm{g} \mathrm{dm}^{-3}$ of $\mathrm{SiO}_{2}$, reaching a maximum height of $0.8 \mathrm{~m}$ per tomato plant. Pires et al. (2009) found that tomato plants with greater height at the initial stage of development tend to be more productive.

The variables SFW and NL were not significantly influenced by the addition of $\mathrm{SiO}_{2}$; however, both variables presented a positive linear correlation with plant height (Fig. 2). Porto et al. (2014) used these variables to infer optimal nutrition conditions for tomato plants and determined that plants that receive adequate nutrition have a certain balance between the values of the mentioned variables, affirming that plants with a greater height, weight and number of leaves are better-nourished plants. Pulz et al. (2008), studying the effect of silicates on potatoes, also observed that the height of plants was greater 
in the presence of silicon. The same authors demonstrated that higher growth of potato plants may be associated with higher availability of phosphorus in soils with a higher silicon content. The silicates exert competition for the adsorption sites of phosphorus, causing the sites to be saturated or blocked by silicate anions, increasing phosphorus adsorption (Pulz et al., 2008). Similarly, Prado and Fernandes (2001) also observed a higher available phosphorus content in soil treated with silicate.

For MFPA and MSPA, no significant correlation was observed between DM\% and FP and NG. However, lower DM (\%) indexes were obtained at the extremes (Fig. 3), that is, with the highest and lowest pathogen infection, which coincided with the lowest and highest doses of $\mathrm{SiO}_{2}$, respectively. Therefore, both high pathogen infection and high $\mathrm{SiO}_{2}$ doses negatively

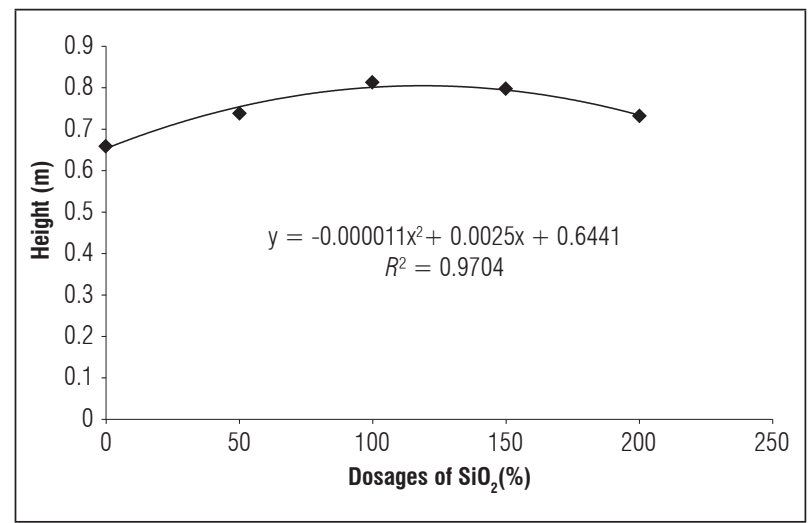

Figure 1. Effect of different dosages of $\mathrm{SiO}_{2}$ on the height of tomato plants. affect the development and accumulation of dry matter in these plants. Rahi et al. (1988) found that the dry and fresh biomass of tobacco plants infected with $M$. incognita and $M$. javanica were almost half of the biomass of uninfected plants.

The different doses of $\mathrm{SiO}_{2}$ affected the formation of galls in the roots of the inoculated plants (Fig. 4): the higher the $\mathrm{SiO}_{2}$ dose, the lower the number of galls. These results are similar to those found by Moreira et al. (2013), where the number of galls formed by M. incognita was lower as a result of the application of different doses of eugenol in a tomato crop. This author stated that the number of galls is directly associated with the amount of nematodes that can penetrate

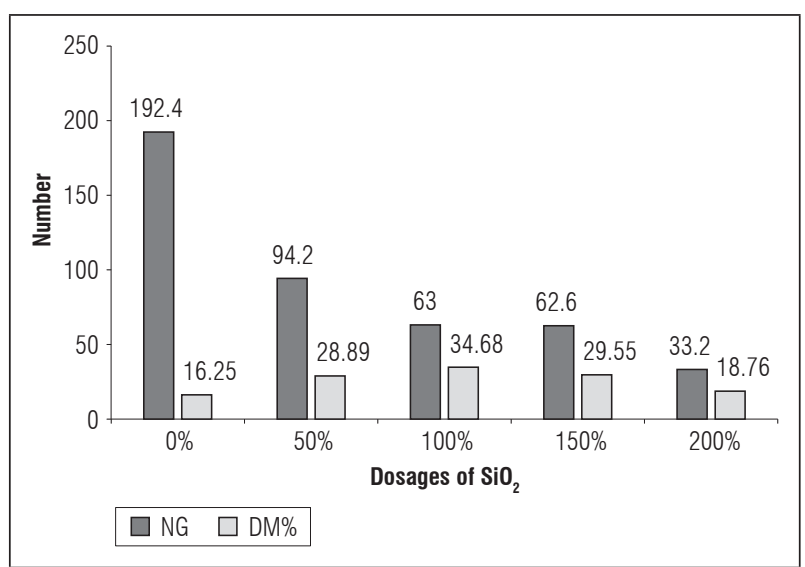

Figure 3. Relationship between the number of galls (NG) in the roots of the plants and percentage of dry matter (DM \%) in the shoot at the different doses of $\mathrm{SiO}_{2}$.
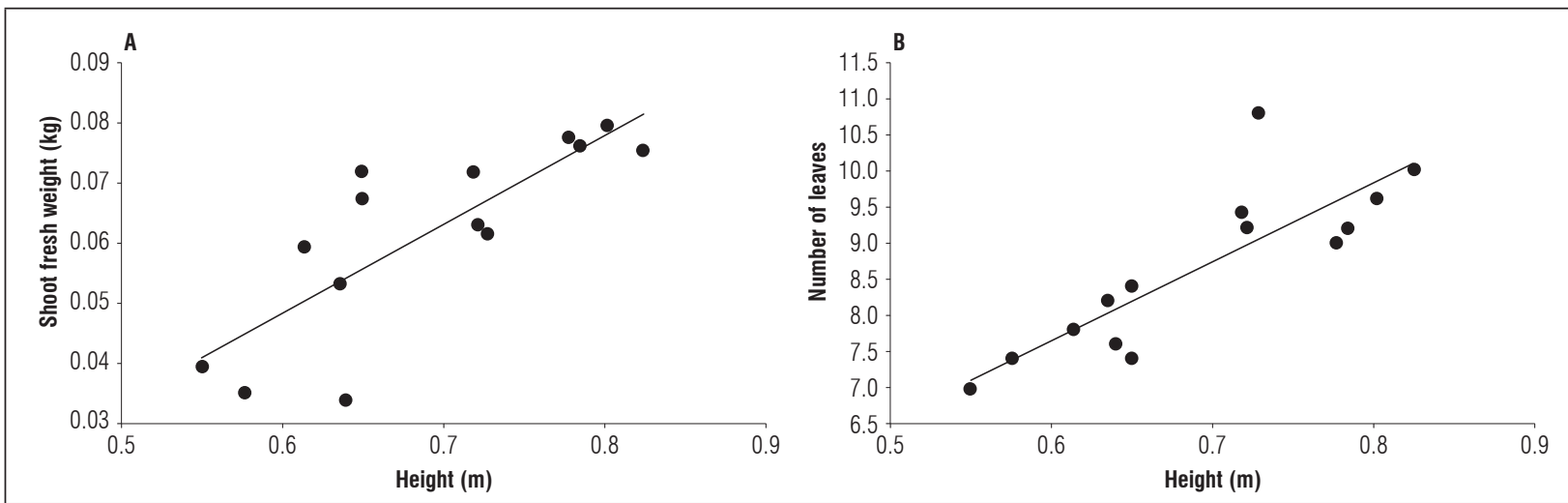

Figura 2. Correlation between plant height and the variables shoot fresh weight and number of leaves per plant. A. Pearson correlation coefficient at $5 \%$ probability $(r=0.81, P \leq 0.0001)$; B. Pearson correlation coefficient at $5 \%$ probability ( $r=0.83 ; P \leq 0.0001)$. 
and settle inside roots. Thus, a lower number of galls also means less penetration of the pathogen in the tissues of the roots, inferring that $\mathrm{SiO}_{2}$ was able to induce resistance to the attack of the pathogen, possibly by a physical barrier formed by Si, inhibiting the penetration of the pathogen.

The final population in the roots did not show dependence on the tested $\mathrm{SiO}_{2}$ doses, so it was not possible to propose a regression model to determine silicon concentrations capable of reducing FP. However, the number of galls had a positive correlation with the final population (Fig. 5), meaning FP depends on the number of galls, increasing as the number of galls increases. This relationship occurs because galls are modified cells where gall-forming nematodes settle and extract nutrients to complete their life cycle

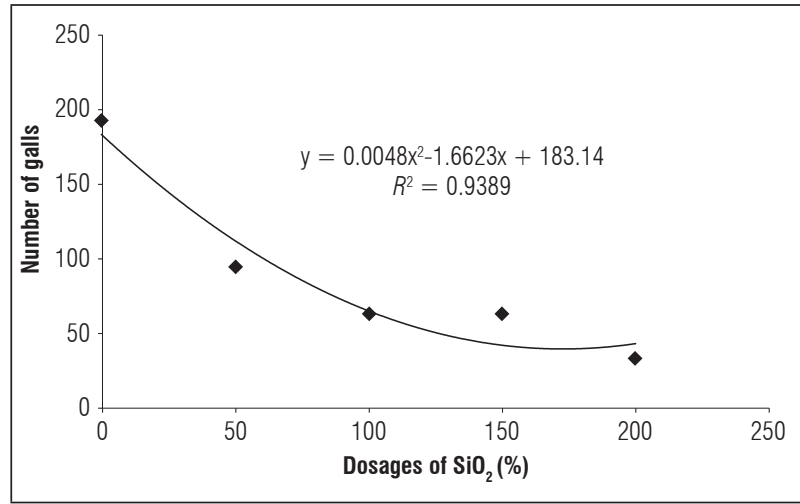

Figure 4. Effect of the different doses of $\mathrm{SiO}_{2}$ on the number of galls (NG) in the roots of tomato plants.

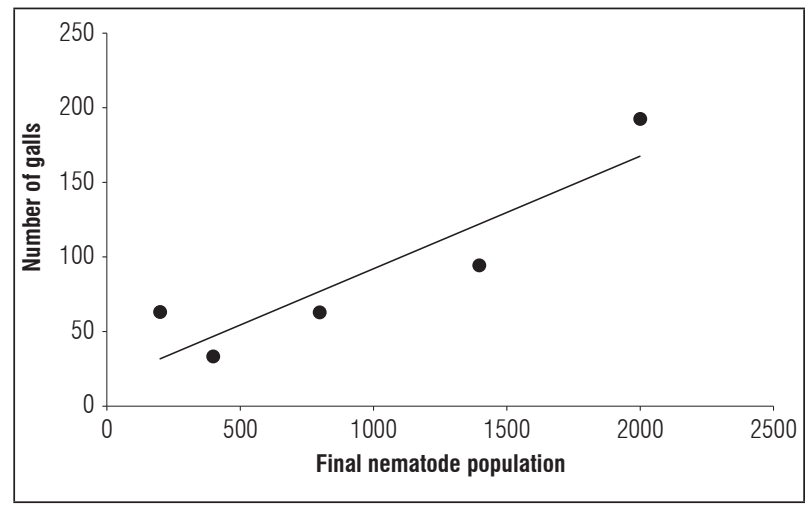

Figure 5. Correlation between the final nematode population (FP) and the number of galls (NG) in the roots of tomato plants. Pearson correlation coefficient at $5 \%$ probability $(r=0.90, P<0.035)$. and multiply. Therefore, the final population of the pathogen tends to be proportional to the number of modified cells present in the roots of the infested plants (Danchin et al., 2016; Ralmi et al., 2016).

Another variable that was influenced by the different doses of $\mathrm{SiO}_{2}$ was Pgr. It can be observed from Figure 6 that Pgr had lower values than the control, where silicon was not added, once again showing that silicon was able to reduce penetration and the consequent multiplication of nematodes inside the root tissues.

Several other authors have found positive results in the use of Si for the management of stresses of a biotic or abiotic origin in both tomato and other crops. Conceição et al. (2014) observed that the application of potassium silicate, alone or in combination with microorganisms antagonistic to the bacterial stain of melon fruits, reduced the severity of the disease. The disease index was reduced by $87 \%$, and the the area was reduced by $65 \%$ when using Si with the antagonistic Rhodotorula aurantiaca Saito in the management. Cao et al. (2017) observed that Si can act as a mediator in tomato plants subjected to water stress, reducing the harmful effects. Sousa et al. (2013), studying the infection processes of Puricularia oryzae (Cooke) Sacc in wheat fertilized with Si, observed that the presence of Si reduced the symptoms of the disease in wheat leaves, emphasizing the possibly that, in the areas where the Si concentration was higher, the fungus penetrated less and had greater difficulty in colonizing. Mattei et al. (2015) observed that the hatching of $M$. javanica eggs was reduced in the presence of Si. In the tomato, a possible deposit of

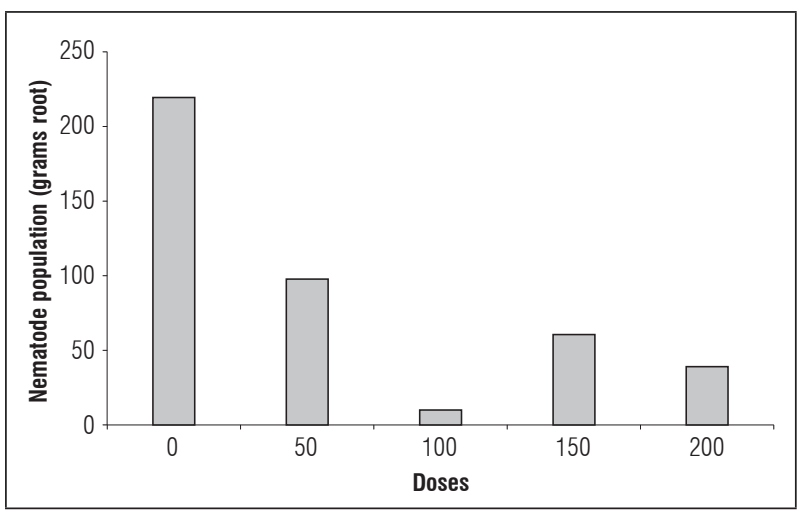

Figure 6. Relationship between the nematode population per gram of infected root and the different doses of silicon dioxide. 
silicon in the root epidermis may have inhibited both the penetration of nematodes and their reproduction inside the cells.

The resistance to pathogen action conferred by the use of silicon is mainly related to the physical barrier formed by salicylic acid in the cells of the epidermis at the penetration points of the pathogen, improving the mechanical resistance of the cells. Silicon accumulates mainly in the cell wall, forming a cellulosesilicon bond that changes the natural barrier of the plant. It changes the anatomy and increases thickness as a result of a greater degree of silicification and accumulation of lignin and phenolic compounds in the lesions (Mendes et al., 2011), affecting the signs of recognition between the plant and the pathogen (Chérif et al., 1994), the latter being a more efficient and enduring form of the resistance mechanism. Cao et al. (2017) affirmed that the greater accumulation of $\mathrm{Si}$ in the roots can maintain the integrity of the cell by improving its mechanical properties after observing a higher Si content in the roots of tomato plants that received a Si application. Besides the formation of the mechanical barrier, the presence of silicon in a plant can improve the activity of plant defense enzymes, inducing the production of antimicrobial compounds and acting in the regulation of plant protection pathways, such as the routes of jasmonic acid, salicylic acid and ethylene. Moreover, it can influence the gene expression of plant defense proteins (Bockhaven et al., 2013; Bhatt and Sharma, 2018). Although the protection mechanisms provided by Si were not evaluated in this study, there is sufficient evidence in the results and in the literature that confirms $\mathrm{Si}$ is able to reduce the penetration and reproduction of $M$. incognita in tomato plants.

\section{CONCLUSION}

The use of $\mathrm{SiO}_{2}$ in the tomato crop provided a higher vegetative performance in the initial phase of development.

The application of $\mathrm{SiO}_{2}$ reduced the final nematode population in the roots of the plants and was efficient in the management of $M$. incognita in this crop.

Conflict of interests: this manuscript was prepared and reviewed with the participation of the authors, who declare that there exists no conflict of interest that puts at risk the validity of the presented results.

\section{BIBLIOGRAPHIC REFERENCES}

Alvarez V., V.H and A.C. Ribeiro. 1999. Calagem. In: Ribeiro, A.C., P.T.G. Guimarães, and V.H. Alvarez V. (eds.). Recomendação para o uso de corretivos e fertilizantes em Minas Gerais: $5^{\mathrm{a}}$ Aproximação. Comissão De Fertilidade Do Solo Do Estado De Minas Gerais, Viçosa, Brazil.

Bhatt, D. and G. Sharma. 2018. Role of silicon in counteracting abiotic and biotic plant stresses. Int. J. Chem. Stud. 6(2), 1434-1442.

Bockhaven, J.V., D. Vleesschauwer, and M. Höfte. 2013. Towards establishing broad-espectrum disease resistance in plants: silicone leads the way. J. Exp. Bot. 64(5), 1281-1293. Doi: 10.1093/jxb/ers329

Bonetti, J.I.S. and S. Ferraz. 1981. Modificações do método de Hussey e Barker para extração de ovos de Meloidogyne exigua em raízes de cafeeiro. p. 553. In: Proc. XIV Congresso da Sociedade Brasileira de Fitopatologia. Porto Alegre, Brazil.

Cao, B.-L., L. Wang, S. Gao, J. Xia, and K. Xu. 2017. Silicon-mediated changes in radial hydraulic conductivity and cell wall stability are involved in silicon-induced drought resistance in tomato. Protoplasma 254(6), 2295-2304. Doi: 10.1007/s00709-017-1115-y

Carvalho, C.R.F., N.J. Ponciano, P.M. Souza, C.L.M. Souza, and E.F. Sousa. 2014. Viabilidade econômica e de risco da produção de tomate no município de Cambuci/RJ, Brasil. Ciên. Rural 44(12), 2293-2299. Doi: 10.1590/0103-8478cr20131570

Chérif, M., A. Asselin, and R.R. Bélanger. 1994. Defense responses induced by soluble silicon in cucumber roots infected by Pythium spp. Phytopathology 84, 236-242. Doi: 10.1094/Phyto-84-236

Conceição, C.S., K.C.S. Félix, R.L.R. Mariano, E.V. Medeiros, and E.B. Souza. 2014. Combined effect of yeast and silicon on the control of bacterial fruit blotch in melon. Sci. Hortic. 174, 164-170. Doi: 10.1016/j. scienta.2014.05.027

Dalastra, C., A.R. Campos, F.M. Fernandes, G.L.M. Martins, and Z.R. Campos. 2011. Silício como indutor de resistência no controle do tripes do prateamento Enneothrips flavens moulton, 1941 (Thysanoptera: Thripidae) e seus reflexos na produtividade do amendoinzeiro. Ciênc. Agrotec. 35(3), 531-538. Doi: 10.1590/S1413-70542011000300014

Damalas, C.A. and I.G. Eleftherohorinos. 2011. Pesticide exposure, safety issues, and risk assessment indicators. Int. J. Environ. Res. Public Health 8(5), 1402-1419. Doi: 10.3390/ijerph8051402

Danchin, E.G.J., E.A. Guzeeva, S. Mantelin, A. Berepiki, and J.T. Jones. 2016. Horizontal gene transfer from bacteria has enabled the plant-parasitic nematode 
Globodera pallida to feed on host-derived sucrose. Mol. Biol. Evol. 33(6), 1571-1579. Doi: 10.1093/molbev/ msw041

Dannon, E.A. and K. Wydra. 2004. Interaction between silicon amendment, bacterial wilt development and phenotype of Ralstonia solanacearum in tomato genotypes. Physiol. Mol. Plant Pathol. 64(5), 233-243. Doi: 10.1016/j.pmpp.2004.09.006

Dias, M.H., J.A. Barbosa, F.F. Peters, J.R. Stangarlin, and R.L. Esteves. 2016. Controle alternativo de Meloidogyne incognita em tomateiro. Sci. Agrar. Parana. 15(4), 421426. Doi: 10.18188/1983-1471/sap.v15n4p421-426

Ferreira, N.C., E.P. Vendruscolo, A. Seleguini, W.S. Dourado, C.G.S. Benett, and A.R. Nascimento. 2017. Crescimento, produção e qualidade de frutos de tomateiro em cultivo adensado com uso de paclobutrazol. Rev. Colomb. Cienc. Hortic. 11(1), 72-79. Doi: 10.17584/ rcch.2017v11i1.5690

Guimarães, M.A., D.J.H. Silva, L.A. Peternelli, and P.C.R. Fontes. 2009. Distribuição de fotoassimilados em tomateiro com e sem a retirada do primeiro cacho. Biosci. J. 25(5), 83-92.

Hunt, D.J. and Z.A. Handoo. 2009. Taxonomy, identification and principal species. pp. 55-88. In: Perry, R.N., M. Moens, and J.L. Starr (eds.). Root-knot nematodes. CABI International, Cambridge, UK. Doi: 10.1079/9781845934927.0055

Hussey, R.S. and K.R. Barker. A. 1973. Comparison of methods collecting inocula of Meloidogyne spp. including a new technique. Plant Dis. Rep. 57(12), 1025-1028.

IBGE, Instituto Brasileiro de Geografia e Estatística. 2016. Agricultura, pecuária e outros. In: http://www.ibge. gov.br; consulted: June, 2016.

Mattei, D. and C.R. Dias-Arieira. 2015. Different sources of silicon in the embryonic development and in the hatching of Meloidogyne javanica. Afr. J. Agric. Res. 10(52), 4814-4819. Doi: 10.5897/AJAR2015.10207

Melo, T.A., I.M.R.S. Serra, G.S. Silva, and R.M.S. Sousa. 2012. Produtos naturais aplicados para manejo de Meloidogyne incognita em tomateiros. Summa Phytopathol. 38(3), 223-227. Doi: 10.1590/ S0100-54052012000300007

Mendes, L.S., C.H.E. Souza, and V.J. Machado. 2011. Adubação com silício: influência sobre o solo, planta, pragas e patógenos. Cerrado Agrociências 2, 51-63.

Moreira, F.J.C. and A.C.S. Ferreira. 2015. Controle alternativo de nematoide das galhas (Meloidogyne enterolobii) com cravo de defunto (Tagetes patula L.), incorporado ao solo. Holos 31(1), 99-110. Doi: 10.15628/ holos.2015.1600

Moreira, L.C.B., B.S. Vieira, C.L. Mota Júnior, E.A. Lopes, and E.J. Canedo. 2013. Ação nematicida do eugenol em tomateiro. Pesqui. Agropecu. Trop. 43(3), 286-291. Doi: 10.1590/S1983-40632013000300011
Oliveira, R.M., R.C.F. Ribeiro, A.A. Xavier, L. Pimenta, and G.K. Korndorfer. 2012. Efeito do silicato de cálcio e magnésio sobre a reprodução de Meloidogyne javanica e desenvolvimento de mudas de bananeira prata-anã. Rev. Bras. Frutic. 34(2), 409-415. Doi: 10.1590/ S0100-29452012000200013

Paim, L.A., R. Carvalho, C.M.P. Abreu, and M.C. Guerreiro. 2006. Estudo dos efeitos do silício e do fósforo na redução da disponibilidade de metais pesados em área de mineração. Quím. Nova 29(1), 28-33. Doi: 10.1590/ S0100-40422006000100007

Pastori, P.L., R.M.C. Filgueiras, A.H. Oster, M.G. Barbosa, M.R.S. Silveira, and L.G.G. Paiva. 2017. Postharvest quality of tomato fruits bagged with nonwoven fabric (TNT). Rev. Colomb. Cienc. Hortic. 11(1), 80-88. Doi: 10.17584/rcch.2017v11i1.5839

Peluzio, J.M., V.W.D. Casali, N.F. Lopes, G.V. Miranda, and G.R. Santos. 1999. Comportamento da fonte e do dreno em tomateiro após a poda apical acima do quarto cacho. Ciên. Agrotéc. 23, 510-514.

Pinheiro, J.B., L.S. Boiteux, R.B. Pereira, M.R.A. Almeida, and R.M.D.G. Carneiro. 2014. Identificação de espécies de Meloidogyne em tomateiro no Brasil. Boletim de Pesquisa e Desenvolvimento, Embrapa, Brasilia.

Pires, R.C.M., P.R. Furlani, E. Sakai, A.L. Lourenção, E.A. Silva, A. Torre Neto, and A.M.T. Melo. 2009. Desenvolvimento e produtividade do tomateiro sob diferentes freqüências de irrigação em estufa. Hortic. Bras. 27(2), 228-234. Doi: 10.1590/S0102-05362009000200019

Porto, J.S., Y.F. Amorim, T.N.H. Rebouças, O.L. Lemos, J.M.Q. Luz, and R.Q. Costa. 2014. Índice SPAD e crescimento do tomateiro em função de diferentes fontes e doses de nitrogênio. Sci. Plena 10(11), 1-8.

Prado, R.M. and F.M. Fernandes. 2001. Efeito da escória de siderurgia e calcário na disponibilidade de fósforo de um Latossolo Vermelho-Amarelo cultivado com cana-de-açúcar. Pesq. Agropec. Bras. 36(9), 1199-1204. Doi: 10.1590/S0100-204X2001000900014

Prezotti, L.C., J.A. Gomes, G.G. Dadalto, and J.A. Oliveira. 2007. Manual de recomendação de calagem e adubação para o estado do Espírito Santo. $5^{\mathrm{a}}$ aproximação. SEEA; INCAPER; CEDAGRO, Vitória, Brazil.

Pulz, A.L., C.A.C. Crusciol, L.B. Lemos, and R.P. Soratto. 2008. Influência de silicato e calcário na nutrição, produtividade e qualidade da batata sob deficiência hídrica. Rev. Bras. Ciênc. Solo 32(4), 1651-1659. Doi: 10.1590/S0100-06832008000400030

Ralmi, N.H.A.A., M.M. Khandaker, and N. Mat. 2016. Occurrence and control of root knot nematode in crops: a review. Aust. J. Crop Sci. 10(12), 1649-1654. Doi: 10.21475/ajcs.2016.10.12.p7444 
Rahi, G.S., J.R. Rich, and C. Hodge. 1988. Effect of Meloidogyne incognita and $M$. javanica on leaf water potential and water use of tobacco. J. Nematol. 20(4), 516-522.

Rosal, J.M.O., J.N. Westerich, and S.R.S. Wilcken. 2014. Reação de genótipos e híbridos de tomateiro à Meloidogyne enterolobii. Ciênc. Rural 44(7), 1166-1171. Doi: 10.1590/0103-8478cr20130041

Sousa, R.S., F.A. Rodrigues, D.A. Schurt, N.F.A. Souza, and M.F.A. Cruz. 2013. Cytological aspects of the infection process of Pyricularia oryzae on leaves of wheat plants supplied with silicon. Trop. Plant Pathol. 38(6), 472477. Doi: 10.1590/S1982-56762013000600002

Timper, P. 2014. Conserving and enhancing biological control of nematodes. J. Nematol. 46(2), 75-89.

Wang, M., L. Gao, S. Dong, Y. Sun, O. Shen, and S. Guo. Role of silicon on plant-pathogen interactions. Front. Plant Sci. 8, 701. Doi: 10.3389/fpls.2017.00701 